\title{
A Aplicação Extraterritorial de Leis Nacionais
}

\author{
José Carlos Magalhães
}

\author{
I - INTRODUGAO \\ II - COMPETENCIA TERRITORIAL \\ III - COMPETENCIA EXTRATERRITORIAL \\ III.1 - Princípio da Nacionalldade \\ III.2 - Princípio da Segurança Nacional \\ III.3 - Princípio da Universalidade \\ III.4 - Principio da Personalidade Passiva \\ III.5 - Princípios da Territorialidade Subjetiva e Objetiva \\ IV - TEORIA DO IMPACTO TERRITORIAL \\ V - APLICACAO EXTRATERRITORIAL DE LEIS ANTIMONOPOLIO
}

\section{I - Introdução}

As atividades transnacionais das empresas multinacionais têm levado os Estados a buscar fórmulas jurídicas capazes de lhes dar suporte a suas pretensões de controle e submissão do complexo empresarial, muitas vezes multinacional. A aplicação extraterritorial das leis antitruste do Estados Unidos oferece o mais significativo esforço nesse sentido.

Promulgados para manter a pureza do sistema competitivo do mercado americano, o Sherman Act, de 1890, o Federal Comission Act e o Clayton Act, de 1914 tratam de impor sanções penais e civis às práticas comerciais que importem em restrições à competição, à concorrência desleal ou resultem em monopólios de produção ou comercialização de bens, no território de qualquer dos Estados Membros.

O Sherman Act estabelece, em termos amplos e vagos, a ilegalidade de todo o contrato ou acordo em forma de fiducia (trust) que tem por objetivo ou do qual resulte restrições ao comércio entre os Estados Membros da União Norte Americana, estabelecendo sanções criminais contra aqueles que monopolizem o comércio de produtos 
e bens entre os Estados ou destes com outros países. Ao lado desse efeito criminal, prevê a lei sanções civis, ao conferir ação aos prejudicados pelas práticas restritivas ou monopolísticas para recobrar perdas e danos (arts. 1, 2, 4 e 7).

O Federal Trade Comission Act declara ilegais quaisquer «métodos desleais de competição no comércio», coibindo, assim, a concorrência desleal (15 U.S.C. § 45 (2) 1964).

O Clayton Act, por seu turno, torna ilegais as fusões e incorporações de empresas que resultem em diminuição da competição, tentando criar uma situação monopolística (Seção 7 do Clayton Act).

Essas três leis constituem as chamadas leis antitruste, interpretadas pelos tribunais americanos de maneira elástica, dados os termos vagos em que se encontram redigidas. Essa interpretação, nem sempre lógica e coerente, ${ }^{(1)}$ tem sido feita através de construção jurisprudencial típica do sistema anglo-saxônico do direito comum, em que os tribunais, a partir dos princípios enunciados em leis escritas, passam a adequá-los aos casos concretos, com autonomia muito maior da que possuem os tribunais dos países que adotam o sistema do direito codificado, de tradição romana.

A constante evolução das práticas mercantis e a dinâmica empresarial, que é responsável pelo aparecimento reiterado de formas novas de associação e de exploração industrial ou comercial, tem feito com que a jurisprudência norte-americana sobre atividades monopolísticas apresente flexibilidade muito grande, permitindo ao Juiz e às autoridades encarregadas de zelar pela aplicação das leis antitruste, usar de grande discrição na definição e no enquadramento de fatos no âmbito do ilícito. Isto causa certa perplexidade ao próprio jurista que, nem sempre, se encontra em condições de definir o «estado atual da lei», ou amplitude de sua aplicação $\left(^{2}\right)$.

O objetivo primordial da legislação antitruste e de sua interpretação dinâmica pelas autoridades e tribunais americanos é o de preservar o sistema competitivo em sua pureza, com a proscrição permanente de práticas desleais de concorrência, o monopólio, os cartéis, as associações e os acordos que resultem, em última análise, na diminuição ou no enfraquecimento das forças vivas da concorrência e da livre competição, premissa básica do sistema econômico americano.

Por causa desse caráter, é que essas leis são encaradas como expressão genuina do sistema americano, sendo descritas oficialmente como «um instrumento americano para assegurar a economia competitiva, na qual repousa em parte a liberdade política e social, sob

(1) EARL A. SNYDER, «Foreign Investment and Trade: Extraterritorial Impact of United States Antitrust Law» in The Virginia Journal of International Law, vol. 6, p. 3.

(2) GEORGE WINTHROP HAIGHT, «International Law and Extraterritorial Applica. tion of the Antitrust Law》 in The Yale Law Jornal, vol. 63, p. 639 (1954). 
governo representativo» $\left({ }^{3}\right)$. Possuem, assim, conotação regional, umbelicalmente ligadas ao sistema econômico que visam preservar, ao lado dos demais valores a ele atinentes.

Não obstante objetive proteger esses valores dentro do território dos Estados Unidos e no âmbito territorial da aplicabilidade das leis, a legislação antitruste passou a ter efeitos extraterritoriais, ao alcançar acordos, cartéis e associações concertados fora dos Estados Unidos, envolvendo empresas americanas e não americanas em áreas jurisdicionais independentes. Ao persistir no propósito de submeter à política antimonopólio americana os eventos que transcendem os limites da jurisdição territorial dos Estados Unidos, estão as autoridades desse país invadindo competências alheias, dando nascimento à conflitos de competências, com outros países. E, para justificar essa jurisdição extraterritorial, rem sempre os Estados Unidos apresentaram explicações convincentes capazes de sensibilizar os demais estados $\left(^{4}\right)$.

$\mathrm{Na}$ verdade, embora tradicionalmente apegados ao princípio da jurisdição territorial $\left({ }^{5}\right)$, conseqüência possível de seu antigo isolamento geográfico, os EUA passaram a aplicar suas leis antimonopólio a eventos ocorridos no exterior, envolvendo participantes não-americanos, mas cujos efeitos, diretos ou indiretos, ocorressem dentro de seu território. Com a expansão dos investimentos internacionais das empresas americanas, sob incentivo inicial do próprio governo, tiveram as autoridades daquele país de enfrentar a questão das práticas e acordos feitos no exterior pelas empresas americanas ou com a sua participação. Ao fazê-lo, não tiveram dúvidas em submeter ao império da lei americana aqueles eventos, tendo em vista o seu caráter saneador contra distorções do sistema da livre competição. A justificativa inicial fundava-se na legitimidade da extensão do princípio da jurisdição extraterritorial, para submeter às leis do país atos praticados no exterior por seus nacionais, ou com a sua participação. Quando não presente essa premissa, o fundamento da extensão passou a recair no efeito territorial, no impacto sofrido dentro do Estado, pelos eventos ocorridos no exterior.

Esse entendimento foi posto em relevo, pela primeira vez na jurisprudência americana, quando da decisão do caso ALCOA, na qual se sustenta que:

(3) Relatorio do «The Attorney General's National Committee to Study Antitrust Laws» (1955) in U.S. Government Printing Office, p. 1 - apud JENNINGS «Extraterritorial Jurisdiction and The U.S. Antitrust Law» in The British Yearbook of International Law (1957).

(4) RICHARD A. FALK, «International Jurisdiction: Horizontal and Vertical Concepctions of Legal Order» in 32 Temple Law Quarterly, p. 295 (1959).

(5) Já em 1812 o Juiz MARSHALL da Suprema Corte dos EUA e um dos «Founding Fathers» da Independência, deixara expresso, em passagem muito citada da decisão do caso «The Schoones Exchange v. Faddon» que «a jurisdição do país em seu próprio território é necessariamente exclusiva e absoluta e não é susceptivel de qualquer limitação não imposta por ele proprio» - Apud BRIGGS, p. 413, The Law of the Nations, Appleton Century, 29 ed., 1952. 
«... è lei reconhecida... que todo Estado pode impor responsabilidade, mesmo sobre não súditos, por conduta fora de suas fronteiras, que tenha conseqüências dentro delas, as quais o Estado proíbe e estas responsabilidades outros Estados as reconhecerão normalmente» $\left({ }^{6}\right)$.

Essa conclusão representa sensivel alteração nos rumos da jurisprudência norte-americana de respeito ao princípio da jurisdição territorial, firmemente estabelecida já na decisão do não menos conhecido caso American Banana v. United Fruit, em 1909, em que, abordada a questão, a Suprema Corte daquele país, firmara doutrina de certa forma rígida de observância à jurisdição alheia.

A decisão do caso ALCOA e a tendência que com ela se fortaleceu de ampliação da competência para aplicar leis antimonopólio, por interferir em outras jurisdições, deu origem a conflitos, com vivos protestos dos Estados afetados por essa prática.

$\mathrm{Na}$ realidade, a política antimonopólio não representa padrões de valores universais de acatamento geral.

A diversidade nesse particular é flagrante, existindo Estados que até mesmo incentivam monopólios, com ou sem a participação oficial, como ocorre com os países menos desenvolvidos em geral.

Por outro lado, os conceitos antimonopólio começam a ser aceitos em certas áreas de economia mais ativa, como é o caso do Mercado Comum Europeu, onde se coibem as práticas monopolísticas com certo rigor. Outros Estados prevêem essa prática como ilegal, sem dar-lhe a importância e a extensão encontrada nos Estados Unidos.

Além disso, mesmo nos Estados que adotam semelhante norma, os critérios de apreciação são diversos, pois, como informa EARL A. SNYDER,

«as leis sobre práticas restritivas (da concorrência) na maioria dos países, exceto nos Estados Unidos, tendem apreciar a legalidade da conduta nos negócios pelo efeito (desempenho econômico), mais do que pela existência de certa conduta ou forma de agir, que constitui o critério básico da lei antimonopólio dos EUA» (7).

Todos esses fatos levam à consideração do problema da competência para legislar e de aplicar leis no âmbito interno e internacional e sua solução depende do exame das expectativas da comunidade internacional, conjugados com os interesses de cada comunidade nacional. É necessário que se examinem os princípios que informam a competência territorial, como postulados consagrados na ordem internacional e que medida se justifica a ampliação dessa competência.

(6) 148 - Fed 2nd 416 a pg. 443 2nd Circ. 1946.

(7) EARL A. SNYDER, Nota 1, pg. 8. 


\section{II - Competência Territorial}

A ordem jurídica internacional caracteriza-se por ser essencialmente descentralizada, detendo cada Estado competência para legislar e aplicar normas de direito dentro de seu território, ao mesmo tempo em que participa ativamente na elaboração das normas de direito internacional ${ }^{(8)}$. Sendo uma ordem preponderantemente horizontal, no sentido de que cada Estado detém igual autoridade no estabelecimento de normas jurídicas, a distribuição de competências passa a ser essencial para a manutenção da ordem internacional. A delimitação da jurisdição - poder-se-ia mesmo dizer a organização da jurisdição é que constitui a competência legislativa ou judiciária de cada Estado na esfera internacional ( $\left.{ }^{9}\right)$.

Como todos os Estados podem definir livremente sua competência internacional $\left({ }^{10}\right)$, é necessário delimitá-la pela competência e organizá-la de forma a permitir o convivio internacional pacífico.

O primeiro postulado dessa organização de competência consiste exatamente no estabelecimento de alguns princípios básicos e necessários à distribuição das competências.

A jurisdição territorial constitui a premissa básica dessa distribuição. De acordo com esse princípio, os Estados são competentes - e com exclusividade - para legislar, aplicar e executar suas normas de direito, dentro de seus territórios. Se a competência para legislar na ordem internacional é concorrente entre todos os Estados, na ordem interna é universalmente aceito que o Estado detém exclusividade de jurisdição. Qualquer invasão dentro dessa área só é admitida por expresso consentimento do Estado ou pelo acatamento de norma internacional reconhecida por esse mesmo Estado. Em atenção a esse fato é que foi inscrita, no art. 2 da Carta das Nações Unidas, a ressalva de que as suas disposições não interferem em matérias que estejam no âmbito da «jurisdição doméstica dos Estados». Não obstante a controvérsia reinante sobre o que constitui «jurisdição doméstica dos Estados», num mundo em que as relações internacionais tornam as fronteiras permeáveis, o fato é que o que se entender por jurisdição doméstica, constitui competência privativa e exclusiva do Estado.

Há um consenso geral, por outro lado, de que um Estado não pode, salvo se expressamente permitido, exercer o seu poder e autoridade

(8) RICHARD A. FALK, Nota 4, pg. 295.

(9) R.Y. JENNINGS, Nota 3, pg. 148.

(10) AMILCAR DE CASTRO, «Direito Internacional Privado», observa que «não há uniformidade de competência legal mantida pelos direitos estatais e todos estão de acordo em que cada nação pode definir livremente sua competência». $\mathbf{E}$ acrescenta que isso ocorre porque «quanto à origem, o poder jurisdicional é invariavelmente autóctone; e cada governo, por competência legislativa também autóctone, trata com inteira independência de dizer em suas leis quais são as causas que devem, ou não, ser julgadas na esfera de sua jurisdição». Direito Internacional Privado, vol. II, p. 223 - Forense, Rìo, 29 edição, 1968. 
dentro do território de outro Estado (11), o que é conseqüência natural da exclusividade de competência territorial.

A esse propósito, merecem ser lembradas as observações feitas pelo professor dinamarquês ALF ROSS: ${ }^{(12}$ )

«É um fato histórico o de que os Estados são separados um do outro e delimitados territorialmente.

Os Estados são primariamente uma organização de poder. Cada um pretende, dentro de certo território separado dos demais, o supremo poder em relação aos seus súditos (uma comunidade de governo próprio). O mais simples princípio, matéria de quase um curso, para a individualização e separação desses instrumentos de poder competitivos, é o espacial ou territorial».

Aduz o autor ainda que,

«Em conformidade com isso, a norma legal internacional da distribuição da competência é o de que todo Estado é competente e exclusivamente competente dentro de seu próprio território para estabelecer atos os quais, efetiva ou potencialmente, consistem no trabalho do aparato compulsório do Estado (a máxima da supremacia territorial) ».

Essa noção da supremacia territorial é inerente à organização territorial do Estado e está intimamente ligada aos mesmos fatores que condicionaram o nascimento do Estado, como organização política independente. Advém da afirmação de poder do Estado, acatada pelos demais e que se traduz na determinação de sua própria competência ${ }^{(13)}$. A ordem internacional, denominada de primitiva por Kelsen, está estruturada no sentido horizontal (14), e a coordenação das competências dos sujeitos de direito internacional é a tônica característica ( ${ }^{15}$ ).

Nessa coordenação de competências, é princípio assente e universalmente consagrado que cada Estado exerce em seu próprio território uma absoluta e exclusiva jurisdição, aplicando seu direito a todos os eventos ocorridos dentro do território, envolvendo nacionais ou estrangeiros ${ }^{(16)}$.

Assentada essa norma, outros princípios devem ser considerados para abrigar situações em que a competência territorial não é suficiente para solucionar as questões postas na prática. Em verdade, no mundo contemporâneo, a estrita compartimentalização das competên-

(11) JENNINGS, Nota 3, pg. 149.

(12) ALF ROSS, Text Book of Interntional Law, pg. 137/138 (1947).

(13) AMILCAR DE CASTRO, Nota 11, vol. 1, pg. 19 e vol. 2, pg. 48.

(14) RICHARD A. FALK, Nota 4, pg. 292.

(15) AMILCAR DE CASTRO, Nota 11, vol. 1, pg. 21.

(16) JOHN BASSET MOORE, «Territorial Jurisdiction» - Voto dissidente no julgamento do caso «Lotus» - BR/65. The Law of the Nation - pg. 299 (C.P.J.I. - Ser. A - no 10 (1927) pg. 68-69 e 88. Appleton Century Crofts Inc. - New York - 2a ed. 
cias territoriais torna-a de difícil realização prática, dada a multiplicidade de eventos que transcendem as fronteiras dos Estados. Não é nova a ilustração do problema do indivíduo que dispara seu revólver e atinge outro, postado em território de outro Estado.

Aqui a simplicidade do exemplo mostra a complexidade da matéria e a questão posta é a de qual Estado é competente para punir em tal situação: o Estado da vítima, onde o fato produziu efeitos danosos, ou o do agressor, onde a ação se iniciou. Essa questão, de certa forma simples, cresce de dificuldade na medida em que elementos ou eventos transnacionais entram em jogo.

$E$ é justamente para fazer face a tais situações que o princípio da competência territorial começa a ser posto em xeque para admitir efeitos extraterritoriais de normas nacionais, vale dizer, da jurisdição nacional.

\section{III - Competência Extraterritorial}

Os efeitos extraterritoriais da jurisdição do Estado decorrem sempre de um vínculo fático do evento com o território e se justifica sempre em razão desse vínculo, seja ele a nacionalidade dos agentes, seja o objeto de determinado negócio ou relação jurídica, quer ainda se refira a valores que direta ou indiretamente afetem o Estado, em seus dominios territoriais.

Essa aplicação extraterritorial de normas nacionais foi reconhecida no direito internacional, de modo claro, na decisão do caso Lotus, pela Corte Permanente de Justiça Internacional, que acolheu como legítima a ampliação da jurisdição territorial, desde que circunscrita à regras do direito internacional. Em verdade, enfatizou a Corte,

«tudo o que pode ser exigido de um Estado e que não ultrapasse os limites que o Direito Internacional impõe a sua jurisdição; dentro desses limites, seu título para exercer jurisdição repousa em sua soberania» $\left({ }^{17}\right)$.

Importa, assim, verificar os limites que o direito internacional impõe à jurisdição dos Estados e quais os princípios norteadores da extensão dessa jurisdição. Sendo a competência dos Estados uma questão diretamente ligada à organização internacional e à estrutura da ordem internacional, os princípios que informam a jurisdição extraterritorial não derivam do arbítrio de cada Estado, mas da prática comum. $\mathrm{Na}$ verdade, como adverte Jennings, é por essa razão que os Estados não se permitem ilimitada discrição do assunto $\left({ }^{18}\right)$, procurando, ao contrário, pautar-se pelos princípios que informam a prática da comunidade internacional. Esses princípios derivam de certas preocupações comuns

(17) C.P.J.I. - Caso S.S. Lotus - Série A no $10-$ pg. 19 (1927).

(18) JENNINGS, Nota 3, pg. 150. 
dos Estados e suficientemente fortes para impor tolerância recíproca na ampliação extraterritorial da jurisđição.

Alguns desses principios são aceitos quase que universalmente, como o da jurisdição sobre nacionais (nacionalidade), o da universalidade e o da territorialidade objetiva, ou ainda o da segurança do Estado. Outros, como o da personalidade passiva, já não gozam de tanto prestígio, prestando-se a controvérsias. Esses princípios acham-se consagrados no direito interno dos Estados, com maior ou menor uniformidade consoante conclusões da pesquisa realizada pela Harvard Law School em $1935{ }^{(19)}$.

Cada princípio tem sua própria órbita de aplicação, girando em torno de diferentes matérias.

\section{III.1 - Princípio da Nacionalidade}

O princípio da nacionalidade permite aos Estados exercer jurisdição sobre seus nacionais no exterior, regulando-lhes as atividades, porém de forma não conflitante com a competência de outros Estados. Hildebrando Accioly distingue o «jus avocandi», que faculta aos Estados chamar seus nacionais para cumprir determinados encargos impostos pelo Poder Público, do «jus puniendi» que permite ao Estado punir delitos cometidos por seus nacionais no exterior, no momento em que estes retornem ao seu território $\left({ }^{20}\right)$. Quanto a este último, a pesquisa levada a cabo pela Escola de Direito de Harvard em 1935 revelou uniformidade entre os Estados no tratamento da questão, tendo sido proposto, no projeto de Convenção preparado com base nos resultados da pesquisa, o seguinte preceito:

$$
\text { «Art. } 5 \text { - Jurisdição sobre nacionais - }
$$

Um Estado tem jurisdição sobre qualquer crime cometido fora de seu território,

a) Por pessoa natural que era nacional daquele Estado quando o crime foi cometido ou que é nacional do mesmo Estado quando denunciado ou punido ou

b) Por uma empresa ou outra pessoa juridica que tinha nacionalidade do Estado quando o crime foi cometido (21).

Disso resulta que, não obstante cometido o ato tido como delituoso em território sujeito à jurisdição alheia, o Estado possui competência para processar e punir o seu próprio nacional autor do ato. Condição fundamental, como é curial, é a de que o indivíduo adentre o território

(19) «Research in International Law under the Auspices of the Harvard Law School, Jurisdiction with respect of Crime» (1935). 29 A.J.I.I. Supp.

(20) HILDEBRANDO ACCIOLY, Manual de Direito Internacional Pablico, pg. $79.10 *$ ed. (1972) - Ed. Saraiva.

(21) Nota 20 . 
de seu Estado, porquanto o princípio da territorialidade prefere ao outro, não sendo admissivel a aplicação e execução das leis dentro do território alheio. No direito brasileiro, o princípio é consagrado no art. $5 \mathrm{n}^{\circ}$ II «b» do Código Penal, que sujeita à lei brasileira o crime cometido por brasileiro no exterior, condicionando a sua aplicabilidade à entrada do agente no território brasileiro e, dentre outras, a de ser o fato punível também no país em que foi praticado ( $\S 2^{\circ}$ letra «b»).

O problema que, desde logo, é levantado é o da nacionalidade da pessoa jurídica, tendo em vista os diversos critérios formais existentes. Não obstante, como observa Jennings ${ }^{22}$ ), os testes da sede da pessoa jurídica ou o do local de arquivamento dos atos constitutivos possam ser aplicados para a determinação formal na nacionalidade da pessoa jurídica, nada impede que os tribunais prescrutem as reais vinculações da sociedade, para determinar a nacionalidade dos efetivos detentores do controle e, assim, sobre eles, fazer incidir suas leis ${ }^{23}$ ).

Assim, não obstante a pessoa jurídica tenha a nacionalidade formal de um Estado, podem os seus dirigentes, ou, de qualquer forma, os detentores de seu controle, ficar sujeitos à legislação de outro. É o que ocorre, sob este aspecto, com a legislação antitruste do Estados Unidos, aplicada com caráter extraterritorial, quando alcança atos praticados por nacionais no exterior, mesmo que ao abrigo de leis locais ${ }^{(24)}$.

Essa prática faz aflorar um conflito de competências e de qualificações entre os Estados, pois interfere com pessoas jurídicas de outras nacionalidades que estão adstritas a seguir os parâmetros das leis nacionais a que estão sujeitas (25).

\section{2 - Princípio da Segurança Nacional}

De acordo com o principio da segurança nacional, é lícito ao Estado agir em defesa de sua independência política, integridade territorial, segurança interna ou externa, contra quaisquer pessoas, nacionais ou estrangeiros, ainda que os atos tenham sido praticados no exterior e lá concebidos. A jurisdição do Estado afetado se estende extraterritorialmente para alcançar tais atos, sob a condição de que os mesmos não tenham sido praticados no exercício regular de um direito reconhecido no Estado onde foi praticado ${ }^{(26)}$.

(23) JENNINGS, Nota 3, pg. 154.

(23) JOSE CARLOS DE MAGALHAES - \&Nacionalidade da Pessoa Jurfdica e a Empresa Multinacional» - Rev. Faculdade de Direito - Vol. LXIX (Fasc. II) pg. 87; Rev. Forense, vol. 235.

(24) SNYDER, Nota 1, pg. 23 e 32; WILLIAM DWIGHT WHITNEY, \&Sources of Conflit Between International Law and the Antitrust Law» in 63 Yale Law Jonrnal, pg. 655 a 666.

(25) Na verdade, houve evoluça na jurisprudência norte-americana no sentido de năo considerar passivel de puniçăo as responsáveis por atos praticados no exterior em cumprimento a determinações oficiais. US v. Supplled Chemical Industries Ltd. (105 F. Supp. 215 a 242).

(26) Art. 7 do Projeto de Convença de Harvard, Nota 20. 
Essa jurisdição se aplica também quando a moeda, crédito, símbolos públicos, selos, enfim, documentos e papéis que envolvem a credibilidade do Estado, forem objeto de falsificação ou contrafacção (27).

$\mathrm{Na}$ verdade, envolvida a segurança nacional, por qualquer forma ou meio, pode surgir até mesmo a responsabilidade internacional do Estado onde os atos são praticados, caso o mesmo não atue no sentido de impedí-los ou de punir seus autores.

É princípio assente que nenhum Estado está autorizado a praticar atos de governo no território de outro Estado, como o de tornar eficaz suas leis ou o próprio direito internacional. Corolário desse princípio é o controle, pelo Estado, da ordem interna e intenacional em seu território evitando-se a prática de atos atentatórios à segurança de terceiros. Se houver convivência das autoridades ou impossibilidade de exercer esse controle, o Estado afetado estará autorizado até mesmo a substituir-se à autoridade do Estado territorial, para pôr termo às atividades contra ele dirigidas. Esse tema, contudo, não está isento de debates, mormente no momento atual, em que os movimentos de guerrilhas baseados no exterior adquirem força contra o próprio Estado territorial onde se encontrar. $O$ aprofundamento na discussão dessa questão, contudo, refoge ao espírito deste trabalho. $\left({ }^{28}\right)$.

\section{III.3 - Principio da Universalidade}

O fundamento desse princípio é a colaboração recíproca dos Estados em reprimir crimes e atos atentatórios aos princípios éticos da própria humanidade. O crime, onde quer que seja cometido, desde que o ato assim qualificado tenha a mesma consideração em todos os demais Estados, justifica a ampliação da competência para alcançá-lo, ainda quando praticado em locais não sujeitos à autoridade de nenhum Estado. A pirataria, o tráfico de mulheres ou crianças, o tráfico de escravos e, modernamente, o genocídio, constituem crimes caracterizados como atos contra a humanidade e, assim, sujeitos à jurisdição de todos os Estados.

O que justifica a extraterritorialidade da competência do Estado é, assim, a definição do ato como criminoso não apenas no Estado que pretende submetê-lo à sua autoridade, como também no local onde foi praticado. As nuances de diferenças de gradação das penas são resolvidas através de limitações impostas pelos próprios Estados interessados. O Brasil, por exemplo, apenas concede extradição de estran-

(27) Art. 8 do Projeto de Convenção de Harvard, Nota 20.

(28) O tema tratado, sob diferentes enfoques em JIMENES DE ARECHAGA, «International Responsability in Manual of Public International Law, editado por Sorensen, 1968, a pg. 533; DHREK BOWET, «Reprisals Involving Recourse to Armed Force», in A.J.X.L., vol. 66, pg. 26; HENRY MEYROWITZ, «Guerilla et Le Droit de Guerre», in Revue Belge de Droit International, pg. 56; H. LAUTERPACHT, «Revolutionary Activities by Private Persons Against Foreign States», in A.J.I.L., vol. 22, pg. 105. 
geiros se os atos pelos quais estes foram ou estão sendo processados no exterior são também definidos como crime no Brasil, condicionando, entretanto, a entrega do extraditando ao compromisso formal do Estado requerente de que a pena a ser imposta não ultrapasse ao limite máximo previsto para o mesmo ato na legislação brasileira ${ }^{(29)}$.

\section{III.4 - Princípio da Personalidade Passiva}

Alguns Estados ampliam sua competência para fora dos limites territoriais para alcançar eventos ocorridos em outras paragens, nos quais estejam envolvidos, como participantes passivos, nacionais do Estado. Vale dizer, se o evento resulta em lesão criminosa ao seu nacional, o Estado está autorizado a submeter à sua jurisdição os autores, responsáveis pelo resultado danoso. Essa pretensão, contudo, não é de aceitação pacífica entre os Estados, havendo dentre eles, como os que adotam a «common law» como sistema jurídico, que não a reconhecem como justificativa legítima para a ampliação da competência. A jurisprudência internacional, por sua vez, já examinou a questão na decisão do caso Lotus, em que a pretensão turca de submeter a julgamento os responsáveis pelos eventos que resultaram em ferimentos e morte de tripulantes turcos, na colisão de barco turco com navio francês, se fundou, parcialmente, no fato de serem turcas as vítimas, o que justificaria a competência da Turquia em processar e julgar os fränceses responsáveis. Os fatos desse caso são relatados mais adiante.

\section{III.5 - Princípio da Territorialidade Subjetiva e Objetiva}

Os princípios até aqui enumerados tratam especialmente de eventos ocorridos no exterior, para os quais o Estado estende sua autoridade, além de suas fronteiras, para trazê-los à sua órbita de competência. Há, assim, exceções ao princípio da territorialidade; é ele abandonado em face da relevância do próprio evento, envolvendo outros valores que interessam ao Estado, ou seja, o controle de seu nacional, a defesa de sua segurança, afetada por atos praticados no exterior, a perseguição de fatos universalmente definidos como contrários ao direito ou a proteção do nacional, quando alvo de delito cometido no exterior.

Em todos, a territorialidade estrita da competência é substituída por outro critério. No princípio da territorialidade subjetiva ou objetiva, contudo, os Estados passam a alargar o próprio conceito de território para considerar produzido dentro dele o evento ocorrido parcialmente no exterior, para, assim, submetê-lo à competência territorial. O principio da territorialidade objetiva estabelece uma relação de causa e efeito no evento ocorrido parcialmente no exterior e parcialmente dentro do Estado, o que confere aos Estados envolvidos, em igualdade de condições, competência para regular o evento, bem assim, seus participantes. A justificativa, aqui, é a ocorrência parcial do fato no território e, por via de consequência, do impacto social que o 
mesmo causou. O Estado mais afetado pela ocorrência tem, preponderantemente, maior interesse em submetê-la à sua competência territorial. E é a maior ou menor intensidade do impacto no território dos Estados envolvidos que serve de elemento definidor das competências.

De acordo com o critério subjetivista, o Estado possui competência judiciária sobre participantes de eventos iniciados no Estado, mas consumados no exterior, desde que estes adentrem o seu território. No Brasil, o Supremo Tribunal Federal, em decisão freqüentemente citada na doutrina, deixou assente a jurisdição penal brasileira para processar os responsáveis pela explosão de um navio inglês, «The Tennyson», ocorrida em alto mar, os quais colocaram explosivo no navio, em portos brasileiros $\left.{ }^{(30}\right)$. O critério objetivista, ao contrário, permite ao Estado afirmar sua competência sobre eventos iniciados fora, mas consumados dentro do território do Estado. O Juiz John Basset Moore, em passagem sempre repetida e que se tornou clássica, ao comentar a decisão do não menos conhecido caso Cutting, expressou esse critério nos seguintes termos:

«O princípio segundo o qual um homem que, intencionalmente, põe em movimento, fora do território de um país, uma força destinada a produzir efeitos dentro dele, é responsável no lugar onde o mal é produzido, é reconhecido na jurisprudência criminal de todas as nações» ( ${ }^{31}$ ).

A decisão do caso Cutting constitui importante desenvolvimento do princípio, com conseqüências na sua evolução para teoria do impacto territorial, no qual se fundamenta a doutrina e jurisprudência norte-americanas para aplicar suas leis antimonopólio com efeitos extraterritoriais. Os fatos desse caso podem ser assim resumidos: Cutting, um cidadão norte-americano residente no México, publicou um artigo injurioso contra um cidadão mexicano, Emidio Medina, em jornal de circulação local. Levado o caso a juízo, Cutting comprometeu-se a retratar-se, com a publicação da retratação no mesmo jornal, o que cumpriu apenas em parte, ao estampar sua manifestação em tipos minúsculos e com erros de redação que tornaram quase ininteligível o texto. Além disso, no mesmo dia, Cutting publicou na cidade de El Paso, no Texas, no Journal Sunday Herald outro artigo, no qual ratificou as injúrias e calúnias assacadas contra o mexicano. Este voltou a juizo e processou Cutting por calúnia e difamação, sob o fundamento de que, não obstante publicado em território norte-americano, o jornal entrou no México, onde teve larga circulação. Ao decidir a questão, o Juíz mexicano, dentre os fundamentos que o levaram a condenar Cutting e a afirmar a competência do México para conhecer do evento, ratificou a aplicação do princípio da territorialidade objetiva, pois o fato fora praticado no exterior, em território norte-americano mas

(30) BRIGGS, Nota 17, pg. 576.

(31) JOHN BASSET MOORE, «Report in Territorial Crime and the Cutting Case», 1827, pg. 23; BRIGGS, Nota 17, pg. 576; JENNINGS, Nota 3, pg. 156/157. 
seus efeitos principais ocorreram no México. Diz a sentença, em certo trecho:

«Que, mesmo supondo, sem que se aceite o fato, que a ofensa penal de difamação foi cometida no território do Texas, a circunstância de ter o jornal, El Paso Sunday Herald, circulado nesta cidade, fato do qual Medina queixou-se e que foi o fundamento da ordem de apreensão dos exemplares que puderam ser encontrados no escritório de Cutting, nesta mesma cidade, constituiu a consumação do crime, em conformidade com o artigo 614, do Código Pena» ${ }^{32}$ ).

Como se percebe, o fundamento para afirmar a competência mexicana sobre o evento ocorrido no exterior, praticado por estrangeiro, sob as leis de outro país, não foi a extensão da competência territorial, mas a própria competência territorial. O Juiz considerou o crime cometido ou consumado em território mexicano, pelo fato de lá ter circulado o jornal que publicou o artigo considerado calunioso. Essa territorialidade objetiva, não aceita inicialmente pelos Estados Unidos que, a propósito, vigorosamente, se opusera à sentença, em nível diplomático, encontrou também na jurisprudência internacional o seu suporte, com a decisão do caso Lotus, pela Corte Permanente de Justiça Internacional.

Os fatos são os seguintes: em uma colisão em alto mar, entre um navio francês, Lotus, e um navio turco Boz Kourt, este afundou e pereceram 8 de seus tripulantes. Graças ao socorro do navio francês, foram os sobreviventes levados à Constantinopla, onde as autoridades turcas prenderam o oficial de serviço francês, Demons, e o processaram por negligência, considerada como causa do acidente. Com o protesto da França, o caso foi levado à Corte Permanente de Justiça Internacional que, após tecer considerações sobre o problema da jurisdição territorial - cerne da divergência no caso - afirmou, como uma das razões que levaram a justificar a competência da Turquia, que:

«uma vez que é admitido que os efeitos da ofensa se produziram no navio turco, torna-se impossivel sustentar que existe uma regra de direito internacional que proíbe a Turquia de processar o Tenente Demons pelo fato de que o autor da ofensa estava a bordo de navio francês» $\left({ }^{33}\right)$.

$\mathrm{O}$ efeito do ato, tendo-se produzido em território assimilado à Turquia, justificou, assim, a competência territorial, sob o critério objetivista.

A pedra de toque desse princípio são os efeitos diretos do evento dentro do território do Estado que, por isso mesmo, fica em posição legítima para conduzir a questão, dentro de sua esfera de competência.

(32) GRIGGS, «The Cutting Case», Nota 17, pg. 574.

(33) Repertório da Côrte Permanente de Justiça Internacional, série A no 10. 
É necessário, entretanto, que parte do material do evento tenha-se realizado efetivamente dentro do país. De acordo com o princípio subjetivo, o início, a preparação, a realização do ato, cujos efeitos se produzem fora, fundamenta a competência. Pelo princípio objetivo, é o local da consumação, onde os efeitos danosos se fazem sentir, que justifica a asserção da competência.

\section{IV - Teoria do Impacto Territorial}

A partir dos princípios que defluem da competência territorial objetiva, desenvolveu-se, na jurisprudência e doutrina norte-americanas, a teoria conhecida como «impacto territorial», segundo a qual, o Estado possui competência para legislar e conhecer de eventos ocorridos, ainda que integralmente no exterior, envolvendo participantes também não nacionais, desde que tais eventos venham a produzir impacto e a ter efeitos dentro do território do Estado.

O ponto central dessa doutrina de que, embora o evento ocorra no exterior, em área internacional ou dentro de outro Estado, se tal evento produz importante conseqüência no território do Estado, este pode legitimamente aplicar quaisquer meios legais para submeter a seu controle, vale dizer, a sua competência legislativa e judiciária, os autores do evento, a fim de proteger seus interesses ameaçados. Isto $\dot{e}$, o requisito de que parte do evento ocorra efetiva e fisicamente dentro do território, como propugnado pelo princípio da territorialidade subjetiva ou objetiva, é substituído pelo requisito dos resultados ou das conseqüências do fato dentro do território.

A construção da jurisprudência norte-americana, para chegar a esse resultado conceitual, é lenta, mas firme, partindo da consideração inicial de que os efeitos do ato danoso carregam consigo os seus autores. Assim, praticados embora fisicamente no exterior, os agentẹs são considerados como que presentes no local onde os efeitos do ato se produzem. Não há, por isso, uma extensão da competência territorial, mas sim o exercício normal dessa competência no próprio território, onde os participantes imputáveis do resultado danoso são considerados como que presentes, pelos efeitos de seus atos. Os atores são responsáveis não pelo que fizeram no exterior, sob outras leis e jurisdições, mas pelos resultados de seus atos no território do Estado, os quais atraem a presença dos mesmos para o local da consumação desses atos ( $\left.{ }^{34}\right)$.

(34) Em algumas decisóes sobre conflitos de leis entre Estados membros da Uniăo norte-americana, essa fundamentação aparece vigorosa, para justificar a competência de um Estado para julgar sobre evento praticado em outro, como ocorreu no caso People $\nabla$. Adams, em que se diz:

\&O réu pode ter violado a lei de Ohio pelo que ele fez lá, mas com isto não temos nenhuma preocupaçăo.. Ele fol pronunciado pelo que fez aqui e por si próprio. D verdade que o réu não estava pessoalmente dentro do Estado, mas elo estava em propósito Intento o agiu por seus agentes autorizados ... Aqui o crime foi cometido, dentro deste Fstado, e sobre o qual nossas Córte têm indubitavelmente jurisdiçăo». 18463 Den. N.T. (190); JENNINGS, Nota 3, p. 158. 
Com base nessa teoria, os Estados Unidos justificam a aplicação de suas leis antimonopólio e seus regulamentos sobre mercado de capitais, disciplinados pelo Securities Exchange Comission, a fatos ocorridos no exterior, para ter efeito no exterior, com ou sem a participação de nacionais, mas que direta ou indiretamente, venham a afetar o comércio interno ou internacional dos Estados Unidos, influindo nos preços, na produção ou de qualquer forma afetando o mercado americano.

\section{V - Aplicagão Extraterritorial de Leis Antimonopólio}

A aplicação da teoria do impacto territorial na política antimonopólio, ainda que sob as vestes do exercício da competência territorial objetiva, com esse desenvolvimento, traz como consequiência inevitável a aplicação de leis nacionais em território alheio, para regular fatos sob outras jurisdições.

A justificativa encontrada para aplicação de tal teoria em área tão controvertida, quanto à da política antimonopólio, são sempre os efeitos negativos que dentro do território norte-americano podem ter os acordos e contratos feitos no exterior.

Os efeitos no território, traduzidos por interferência no comportamento de preços, na restrição de importações ou exportações, enfim, na economia americana e, mais do que isso, nos princípios que governam o sistema competitivo daquele país serve de fundamento para que, em defesa disso, seus tribunais submetem os seus responsáveis às leis locais.

Essa orientação, firmemente estabelecida a partir da decisão do caso United States v. American Tobacco Co. e consagrada com inusitada ampliação no caso Alcoa v. United States, alterou profundamente os rumos da jurisprudência norte-americana do início do século, de respeito à jurisdições alheias e corporificadas de modo admirável na decisão do clássico caso American Banana v. United Fruit, cujos fatos merecem ser repetidos para dar idéia da evolução da jurisprudência sobre o assunto. A empresa American Banana, de origem norteamericana, ingressou com açã́o contra United Fruit Co., nos Estados Unidos, alegando ter sua concorrente elaborado e posto em execução um plano para assegurar-se do monopólio da plantação de banana na America Central: sob sua inspiração o governo da Costa Rica determinará a apreensão de plantações e equipamento de cultura que American Banana possuía naquele país, retirando-lhe a ligação ferroviária com a costa e impedindo-a, assim, de continuar suas atividades.

Com a subseqüente alienação compulsória das plantações a terceiro, motivada pelos atos governamentais, United Fruit consolidou seu monopólio do comércio do produto na região, especialmente de sua exportação para os Estados Unidos. A existência desse monopólio e a forma como foi conseguido importariam em flagrante violação do 
Sherman Act com reflexos dentro do país. A Suprema Corte dos Estados Unidos, ao decidir a questão, declarou expressamente que o que ocorrera na Costa Rica dependia exclusivamente do governo local, descabendo interferência externa. A Corte chegou a manifestar estranheza em ver-lhe submetido o conhecimento de fatos «causadores de danos, praticados fora da jurisdição dos Estados Unidos e dentro da área de competência de outros Estados». Essa decisão, a propósito, oferece a base para a teoria do «act of state», desenvolvido posteriormente no caso Sabbatino, em que se reconheceu a incompetência dos tribunais nacionais para apreciar atos de natureza política, ou atos de império de outros países ( ${ }^{35}$ ).

A importância desse caso reside no fato de se tratar de questão envolvendo práticas monopolísticas, levadas a efeito por empresa norte-americana, fora do território dos Estados Unidos, tendo a Suprema Corte se pautado estritamente pelo princípio da territorialidade da jurisdição, respeitando a jurisdição e competências alheias.

Mas, dessa orientação, logo se afastou, ao examinar outros casos, sob o fundamento de não-aplicabilidade da regra estabelecida naquela decisão a hipóteses diversas, mas com fundamentos similares, tendo firmado orientação totalmente distinta, com repercussão internacional negativa.

Essa nova postura foi adotada na decisão do caso ALCOA v. UNITED STATES.

A ação teve por objeto o ajuste, na Suíça, de cartel entre empresas não-americanas, com a constituição de uma sociedade denominada ALLIANCE. O objetivo do cartel era a delimitação de produção de lingotes de alumínio fabricados pelos participantes do acordo, pela imposição de quotas proporcionais às ações que cada sócio havia subscrito. Em 1936, o acordo foi alterado e complementado, estabelecendo-se que o participante que desrespeitasse o limite de produção de sua quota deveria pagar regalias à sociedade sobre o excesso produzido Essas regalias deveriam ser distribuídas entre todos os membros de ALLIANCE. Ajustou-se também que as exportações para os Estados Unidos deveriam ser incluídas nas quotas estabelecidas.

Esse acordo perdurou até 1938, quando constatou-se que não mais servia aos interesses das partes, Não obstante, ALLIANCE jamais foi dissolvida ou liquidada, continuando a ter personalidade jurídica, mesmo no periodo de após guerra.

ALCOA, pessoa jurídica americana, com sede nos Estados Unidos, não era parte no cartel, nem sócia de ALLIANCE, embora seus acionistas americanos tivessem participação majoritária na Aluminium Limited, empresa constituida no Canadá, onde tinha sua sede e partícipe do Acordo.

(35) FRANÇOIs RIGAUX, «Droit Public et Drolt Privé dans les Relations Internationales», Pedone, Paris, 1977, p. 339. 
O cartel - como forma privada de regular o mercado internacional de determinado produto ${ }^{36}$ - contrariava as leis antitruste americanas, notadamente a Seção I do Sherman Act. Portanto, seria ilegal se realizado no território dos Estados Unidos.

$O$ ajuste, contudo, foi firmado na Suiça, entre sociedades não-americanas e de acordo com as leis locais. Tratava-se, portanto, de contrato de objeto lícito perante a legislação do país onde foi celebrado.

Não obstante, o governo americano promoveu ação antitruste contra ALCOA e ALUMINIUM LIMITED que, embora canadense, possuía importante escritório nos Estados Unidos, tornando-a sujeita à jurisdição territorial americana.

A Corte que processou a ação decidiu que a conduta fora do território americano poderia ficar sujeita às lei dos Estados Unidos, se se constatasse que tal conduta tivesse produzido reflexos dentro do país. Pelo acordo de 1936 as exportações de lingotes de alumínio para os Estados Unidos estavam sujeitas às limitações das quotas de produção, o que afetava o comércio internacional e a indústria americana.

As objeções opostas por ALUMINIUM LIMITED de que se tratava de acordo firmado na Europa, entre sociedades não-americanas e com obediência às leis da Suíça, não sensibilizaram a Corte, que considerou os efeitos do acordo no território dos Estados Unidos como fundamento suficiente para o exercício da jurisdição americana para regular todas as relações decorrentes do cartel.

As reações contra essa competência extraterritorial logo fizeram-se sentir, não fảltando, entretanto, quem a defendesse com entusiasmo, como o Prof. Myres McDougal, em pronunciamento na Associação de Direito Internacional:

«Quando a Suiça ou Canadá ou qualquer outro país emprega seu aparato governamental para proteger empresários, em atividades que prejudiquem o funcionamento sadio do processo comunitário dentro dos Estados Unidos, eles estão interferindo com os negócios internos e domésticos dos Estados Unidos, tanto quanto os Estados Unidos podem estar interferindo com os negócios de outros países, ao aplicar suas leis antitruste às atividades causadoras de danos. Acordos feitos por empresários privados na Suíça e no Canadá, ostensivamente protegidos pelas leis desses paises, podem afetar ou determinar os preços que eu devo pagar, dentro dos Estados Unidos, pelo alumínio ou relógios. Num mundo interdependente, a interferência recíproca dos Estados no processo comunitário, inclusive nas questões econômicas, é inevitávei. A questão é por que princípios e procedimentos tal interferência pode ser moderada

(36) Cfe. HENRICH KRONSTEIN, The Law of International Cartels - Cornell Univ. Press - 1973 - pg. 39 . 
e reciprocamente tolerada na manutenção e expansão da economia internacional» $\left.{ }^{(37}\right)$.

Outras decisões seguiram-se, adotando a mesma linha de raciocinio: a conduta fora do território do Estado, desde que cause efeitos internos, está sujeita à competência territorial desse Estado. O impacto territorial do evento justificaria a competência.

Essa doutrina reflete, na verdade, a pretensão do Estado de regular, através de leis nacionais, atos e fatos que possuem caráter nítidamente internacional.

Põe ela em evidência a necessidade de reestruturação da ordem internacional face a fenômenos novos que transcendem aos limites territoriais de cada Estado. A competência territorial e os príncipios que governam a competência extraterritorial do direito internacional clássico não se ajustam a essa nova problemática e exige enfoque diverso. George Scelle já dizia que o poder judiciário de cada Estado exerce funções judicantes internacionais e constitui órgão da comunidade internacional descentralizada, competente para decidir questões de caráter internacional no seio do Estado. Essa concepção, cada vez mais, tende a criar raízes, na medida em que a disciplinação de eventos transnacionais não se ajustam a critérios estritos da territorialidade objetiva ou subjetiva do Estado. A jurisdição deve ser exercida em função dos interesses mais elevados da comunidade internacional e o Judiciário deve ser sensível a essa modificação da estrutura do Direito Internacional, compreendendo que, cada vez mais, as relações transnacionais dominam ou tendem a predominar no quadro interno.

Por isso que o exercício da competência extraterritorial a eventos ocorridos no exterior, amparados por leis locais, somente se justifica se princípio internacionalmente aceito for violado. Ou seja, se o Estado, com a aplicação de suas leis, persegue objetivo colimado pela comunidade internacional, sua competência pode estar justificada, pois está atuando como órgão descentralizado dessa mesma comunidade. No caso das leis antimonopólio, contudo, não se pode dizer que haja consenso universal quanto à aceitação dos princípios nela contidos. Estados Unidos e Comunidade Econômica Européia constituem áreas em que a política antitruste se avizinha, embora não coincida. Outros paises distanciam-se ainda mais, como é o caso do Brasil, em que o monopólio estatal e os incentivos governamentais de fusão e incorporação de empresas, a prática de reserva de mercado para indústrias nacionais, em determinados setores produtivos, contrariam frontalmente o princípio da livre competição que norteia a política antimonopólio.

Além do mais, a interferência com a competência alheia é ineficaz se seus efeitos tiverem de ser produzidos no território do país atingido com a invasão legislativa ou judiciária. O princípio da territorialidade da jurisdição, prevalecendo sobre os demais, traz como consequiência a

(37) Relatório da 51 Conferência da Associação de Direito Internacional em Toquio (1965) - Apud STEINER e VAGTZ - Transnational Legal Problems, pg. 928/929. 
necessidade de o Estado territorial aquiescer, através da homologação da sentença estrangeira, com o ato extraterritorial.

Quando isso não ocorre, a sentença é ineficaz e desprovida de executoriedade. Foi o que ocorreu no caso envolvendo Imperial Chemical Industries e Dupont de Nemours (United States v. I.C.I.) decidido nos Estados Unidos. Essas empresas haviam firmado acordos pelos quais a primeira cedia à segunda direitos de exploração de patentes dos Estados Unidos, enquanto que esta conferia àquela os mesmos direitos na Inglaterra. Imperial Chemical Industries (I.C.I.) tinha sede na Grã-Bretanha e passaria, por força desse acordo, a produzir fibra de nylon com exclusividade na Europa, enquanto que Dupont, constituída em Delaware, Estados Unidos, passaria, com as patentes em seu poder, a dominar o mercado americano. Ambas as sociedades associaram-se na América Latina, atuando conjuntamente. Com isso, dividiram-se os mercados, eliminando a concorrência entre os dois grupos empresariais.

As autoridades federais, cientes desses acordos, ingressaram com ação antitruste, objetivando anulá-los e restaurar a livre competição entre as empresas no mercado interno internacional. A Corte determinou à I.C.I. a restituição à Dupont das patentes a ela cedidas na Inglaterra em contrapartida à determinação dirigida à Dupont para que fizesse o mesmo nos Estados Unidos, relativamente às patentes a ela cedidas por I.C.I. e que lhe conferiam monopólio na exploração dos produtos respectivos. Todavia, antes do trânsito em julgado da sentença americana, British Nylon Spinners, concessionária das patentes transferidas à I.C.I., da qual era subsidiária, com sede na Inglaterra, ingressou no judiciário inglês com ação em que pleiteava o não-cumprimento daquela decisão e o reconhecimento da legitimidade dos direitos a ela transferidos livremente por Dupont. $\mathrm{Na}$ verdade, o que pretendeu foi provocar a manifestação do judiciário da Inglaterra sobre o efeito e eficácia extraterritorial da sentença americana ao determinar providência na esfera de competência de outro país. A seguinte passagem da decisão inglesa é ilustrativa da posição adotada:

«Este é um direito, ou, em outras palavras, uma espécie de propriedade (visto, particularmente, que é relacionado a patentes) que tem o caráter inglês e sujeito à jurisdição dos tribunais ingleses. Parece-me que a companhia autora tem a seu favor um caso "prima facie» para dizer que os tribunais dos Estados Unidos ou de qualquer outro país não são competentes para interferir com aqueles direitos ou para expedir ordens cuja observância por nossos tribunais exigiriam que estes não exercessem a jurisdição que possuem e que tem o dever de exercer relativamente a tais direitos».

Mais adiante, acrescenta a decisão:

«E, certamente, a propósito das patentes, parece-me, com todo respeito ao julgamento do «district judge» (americano), 
que se trata de aplicação de uma jurisdição extraterritorial em que não reconhecemos aos tribunais americanos a autoridade para dar ordens que destruiriam ou qualificariam aqueles direitos pertencentes a um nacional inglês, que não é sujeito à jurisdição dos tribunais americanos.

Essa decisão põe em relevo a falta de efetividade da sentença americana, destinada a ser cumprida no país afetado pela extraterritorialidade e competente para apreciar, segundo suas leis, o fato juridico questionado. Aqui, não se cogita do princípio do impacto territorial, pois os fatos ocorreram no território americano, embora parcialmente apenas. Ao pretender a Corte discipliná-los em conjunto, como um todo, deparou com a barreira da competência alheia, à qual teve de se render.

Isto é, embora os eventos tenham uma única origem - divisão de inercados, com restrição à livre concorrência - sua qualificação jurídica fica subordinada à lei do Estado que deve dar efetividade à sentença. Prevalece, portanto, a competência territorial que serve de limite à aplicação de leis ou sentenças estrangeiras. Daí as reações anotadas por Steiner e Vagtz ( ${ }^{38}$ ) de diversos países contra a tendência dos tribunais americanos em estender para o exterior os efeitos das leis antitruste, que caracteriza o sistema econômico americano, mas que não pode ser erigido em princípio internacionalmente aceito, Daí também os reflexos positivos na recusa inglesa em reconhecer efetividade à decisão no caso I.C.I. e Dupont.

Essas reações sublinham as dificuldades em se regular questões internacionais, mediante leis nacionais. Se, no território do Estado, suas leis gozam de eficácia, esse resultado pode não ocorrer no âmbito externo. As diferenças de ideologias político-econômicas, sem se considerar outros componentes, como religião, costumes e graus de desenvolvimento, impedem que cada Estado, por si só, estabeleça padrões de conduta internacional.

Dai que as atividades transnacionais empresas voltadas para a produção ou o comércio internacional de bens não podem ser validamente reguladas por leis nacionais. A aprovação de código de conduta pela Organização Econômica de Cooperação e Desenvolvimento (OECD), que congrega os países desenvolvidos do Ocidente, mais o Japão, reflete, de certa forma, o reconhecimento de que somente por normas internacionais se conseguirá regular tais atividades.

A aplicação de leis nacionais com efeitos extraterritoriais, não obstante bem definidas no direito internacional e amparadas por princípios precisos, não se ajusta a esse fenômeno recente que é o da transnacionalização das relações internacionais.

(38) Materials on Transnational Legal Problems, Foundation Press, pg. 955. 
Importa, pois, indagar sobre a legitimidade da recusa em reconhecer o julgado estrangeiro, concomitantemente com o conteúdo desse julgado. Se a decisão proferida pelo judiciário nacional tem por objeto relação que envolve elemento internacional, tal decisão tem caráter internacional, pois disciplina relação jurídica internacional. A questão da competência judiciária deve, então, ser examinada, ao lado da competência dita legislativa. 